\title{
STRUCTURALLY-CONTROLLED GOLD OCCURRENCES IN THE SOUTHERN BRASÍLIA FOLD-THRUST BELT OF CENTRAL AND SE-GOIÁS
}

\section{JOSÉ OSWALDO DE ARAÚJO FILHO AND RAUL MINAS KUYUMJIAN}

\begin{abstract}
The study of occurrences of hydrothermal alteration products (tin, emerald, barite, and gold), in an area of approximately $28,7000 \mathrm{~km}^{2}$ in the Southern Brasília fold-belt of Goiás, Central Brazil, reveals a strong structural control for these occurrences. Despite the lack of major deposits in the study area, gold has been the main ore mined both in primary lodes and placer deposit, since the $17^{\text {th }}$ century. E-Wtrending intermediate-angle $\left(30^{\circ}-60^{\circ}\right.$ dip angle) thrust-sense shear-zone and NW- and NE-trending high-angle ( $>60^{\circ}$ dip angle) strike-slip shearzone veins are the main Brasiliano host structures of gold deposits. We propose that gold mineralizations were generated as primary deposits mostly in pegmatite and quartz veins associated with the emplacement of pre-Brasiliano S- and early-Brasiliano A-type granitoids. Pervasive Brasiliano deformation dispersed and relocated gold in preferential EW-trending shear zones associated with lateral ramps of E-verging thrusts, frontal ramps of S-SE-verging thrusts, and with NW- and NE-trending shear zones, associated with late-Brasiliano high-angle strike-slip-sense shear zones. These structural controls may indicate targets for further gold exploration in the study area.
\end{abstract}

Keywords: gold, shear zones, structural control, Goiás

INTRODUCTION The study area of $\approx 28,700 \mathrm{~km}^{2}$ is situated in the central and southeastern portion of the State of Goiás, comprising rocks that mainly represent the external and internal zones of the Southern Brasília Belt (SBB) - a Neoproterozoic orogen in the Tocantins Province, Central Brazil, formed during the Brasiliano orogeny. It also includes the metamorphic core of the belt, which is a high-grade terrane of granite gneissic composition that partially composes the geotectonic unit of the Goiás Central Massif. Apart from important industrial material deposits (quartzite and limestone), gold, tin, emerald and barite occurrences have been reported in the region (Giuliani and Araújo Filho 1990, Hoerlle and Wolf-Klein 1977, Ferreira Filho and Brito de Souza 1981), whose origin is related to hydrothermal solutions. Although the region has been prospected for gold since the $17^{\text {th }}$ century, no systematic studies were carried out until now, in order to evince the characteristics of the occurrences. Barbosa and Silva (1992) suggest that the main gold occurrences in SEGoiás State occur within high-angle EW-lateral ramps in shear zones. Therefore, NS and N30W-trending would possibly represent Riedel fractures related with these shear zones. Araújo Filho and Kuyumjian (1996) present a model for the gold occurrences in the region considering a strong structural control by veins associated with shear (both high and intermediate-angle shear zones) and local fractures, the result of the Brasiliano deformation on primary mineralization, possibly associated with pluton emplacements. This paper emphasizes the characteristics of the most important gold mineralizations and evidences the main structural trendlines that control their regional distribution.

REGIONAL GEOLOGY In the study area, the oldest rock types are granite-gneiss, mafic-ultramafic bodies and associated metasedimentary rocks of the Anápolis-Itauçú Complex, of possible Archean age. Tectonically, these rocks are part of a high-grade granitegneiss complex of the collaged Goiás Central Massif (GCM). The mineral isochron (garnet, monazite, and biotite concentrates) of one sample of a sillimanite-bearing granitoid body near the town of Anápolis, metamorphosed to the granulite facies indicated an age of ca. $633 \mathrm{Ma}(\mathrm{Sm} / \mathrm{Nd})$. This is interpreted as representing the first typically Brasiliano age for high-grade rocks in the Brasília Belt (Fischel et al. 1998).

Paleoproterozoic geotectonic units in the study region are volcanicsedimentary sequences, that occur as tectonic slices in the SilvâniaVianópolis and in the Pirineus Syntaxis (PSX) regions. The Rio do Peixe volcanic-sedimentary sequence, dominantly present in the PSX region (Araújo Filho 1981, 1999, Araújo Filho and Marshak 1997, DNPM/CPRM 1994), comprises metaperidotite, amphibolite, garnet amphibolite, meta-andesite, felsic metavolcanic, calcsilicate rocks, metachert and carbonaceous schist, metamorphosed to the greenschist and amphibolite facies. The Silvânia volcanic-sedimentary rocks are similar to those of the Rio do Peixe volcanic-sedimentary sequence. Its lower units comprise actinolite-tremolite schist (meta-ultramafic rock?), garnet amphibolite and meta-andesite, which are overlain by micaschist, quartzite and carbonaceous schist (Araújo Filho 1999 , DNPM/CPRM 1994). These volcanic-sedimentary sequences are overlain by the greenschist facies rocks of the meso/neoproterozoic
Araxá Group (quartz-mica schist, mica-quartz schist, garnet-mica schist, quartzite, garnet quartzite, chloritoid-mica schist and metacarbonate). In the Pires do Rio region, neoproterozoic rocks are represented by metarhyolite and andesitic metatuff of the Maratá Sequence, and quartzite and carbonaceous schist of the Serra do Campo Limpo Sequence, both metamorphosed to the greenschist facies.

In the study area the meso/neoproterozoic rocks are overlain by metarythmite, quartzite and metacarbonate of the neoproterozoic Paranoá Group that display very low-grade metamorphic conditions. The meso/neoproterozoic sequences have been intruded by (neoproterozoic?) granitoids and gabbros, and Mesozoic dykes of diabase and fine gabbro.

The study area comprises rocks of the transitional and internal zone of the Southern Brasília belt and its metamorphic core - the high-grade Granite-gneiss Complex (Anápolis-Itauçú Granulite Complex), as part of collaged tectono-stratigraphic terrane that form the Goiás Central Massif. The Pirineus Syntaxis is the regional structure that separates the more complete Southern Brasília belt (SBB) from the narrower Northern Brasília belt (Araújo Filho and Marshak, 1997 and Araújo Filho, 1999). Rocks of the Araxá and Canastra Groups (metasedimentary rocks of passive margin affinity) compose the transitional and the internal (along with the imbricated thrusts of the Rio do Peixe Group) zone of the SBB, and are in thrust contact with each other. The Araxá Group (in the SW and central portion of the study area; Araújo Filho, 1980, 1981 and 1992b), is in thrust contact with high-grade rocks of the Anápolis-Itauçú granulite complex (Fig. 1). The Paranoá Group, composed of metapsammite, metapelite and metacarbonate, occurs in the NE-corner of the study area (Fig. 1).

The geometry of the SBB in the study area is of a broad antitaxial curve convex to the NE in the PSX region that gradually opens to $\approx$ NS-trendlines to the south. Brasiliano deformation in the SBB is characterized by two strong compressional phases $\mathrm{D}_{1}$ and $\mathrm{D}_{2}$ and a weak $D_{3}$. We characterize $D_{1}$ as the phase that deformed the SBB and that generated east-verging imbricated thrusts, related tight-to-isoclinal folds and a sheath-like belt style in which scoop-like thrusts coalesce in lateral ramps. Deformation intensity increases from east to west and is directly related to prograding metamorphic conditions that range from sub-greenschist to high amphibolite facies. $\mathrm{D}_{2}$ represents a second episode of deformation and is related to the formation of the Northern Brasília belt (Araújo Filho 1999). D -structures verge toward the $S$ and $S E$ and structural style is characterized by a series of frontal thrusts, with no scoop-like structures. $\mathrm{D}_{2}$-structures cross-cut $\mathrm{D}_{1}$ structures and determine fold interference patterns and crenulation foliation. $D_{3}$-structures are characterized by open folds that deform $D_{1}$ and $\mathrm{D}_{2}$ and is weak in intensity of deformation. A late Brasiliano phase of brittle-ductile ENE- and WNW-trending shear zones characterize $\mathrm{D}_{4} . \mathrm{D}_{5}$ is an extensional phase related to the emplacement of Jurassic/ Cretaceous diabase dikes, with no economic importance. $\mathrm{D}_{1}, \mathrm{D}_{2}$ and $\mathrm{D}_{4}$ generated the most important structures that control gold mineralization. $\mathrm{D}_{1}$-lateral ramps determine strong high-angle shear zones and are predominantly EW-trending in the PSX region, but gradually rotate to a WNW-trend southward. $\mathrm{D}_{2}$-thrusts predominantly strike EW in the PSX region and gradually rotate to a NW to NNW 


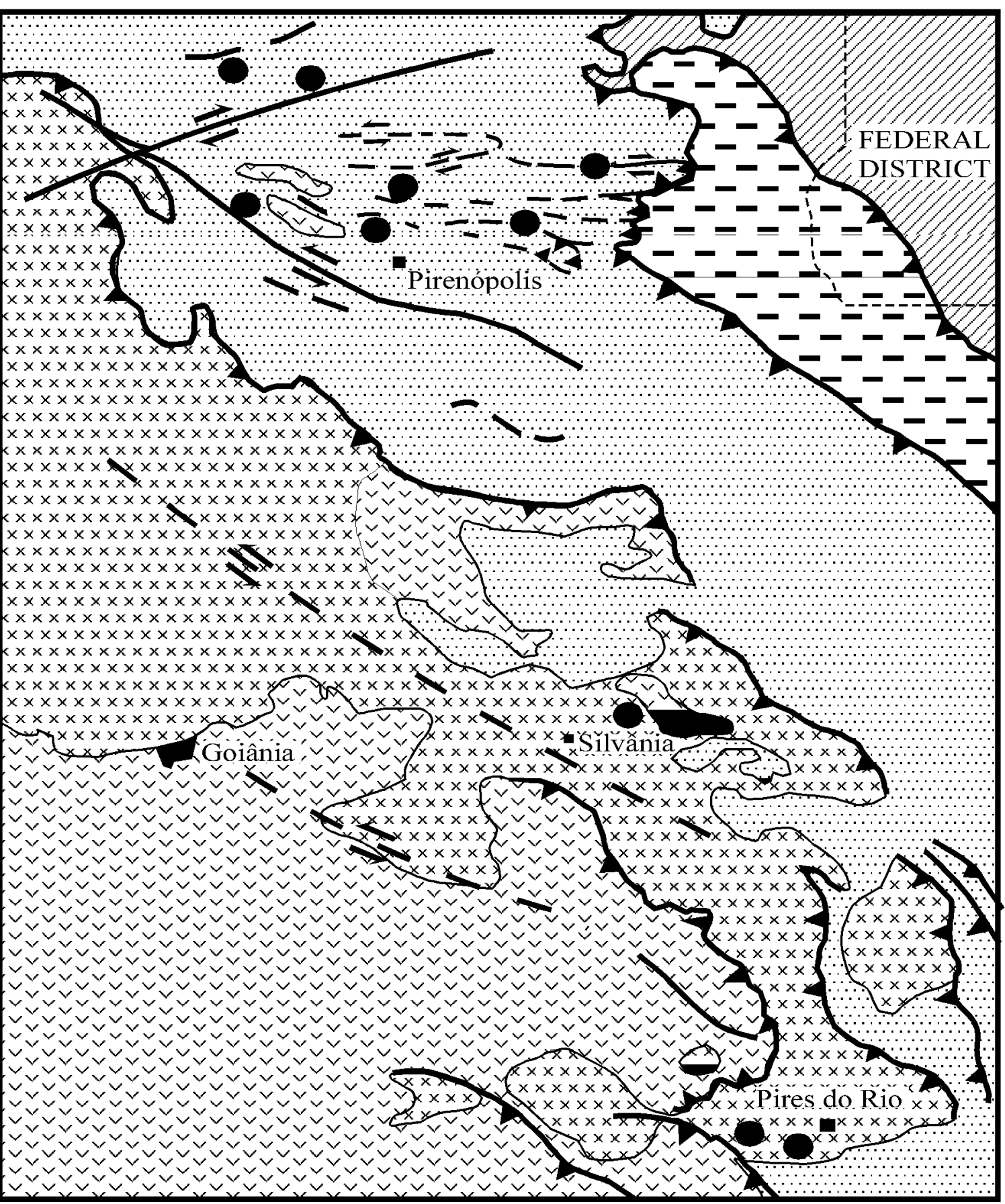

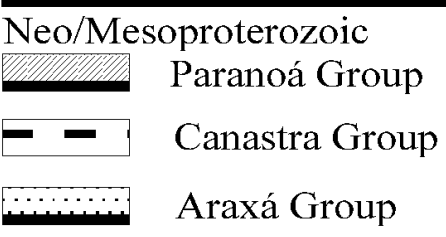

Paleoproterozoic

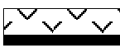

Ophiolites and volcanic-sedimentary sequences

Paleo/Mesoproterozoic (?)

$\times x \times x \times$ Anápolis-Itauçú Granulite Complex

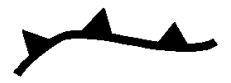

Main Brasiliano E-verging thrusts

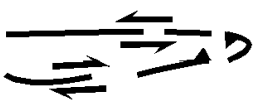

Lateral ramps associated with E-verging thrusts

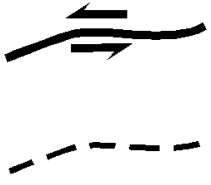

Late Brasiliano high-angle shear zone

Inferred late Brasiliano high-angle shear zone

Gold occurrences 
trend in the SE portion of the study area. $D_{4}$-structures are high-angles shear zones, that were possibly generated in brittle-ductile conditions in $\mathrm{D}_{1}$ and were reactivated in late $\mathrm{D}_{3}$, deforming pre-existing quartz veins and remobilizing fluid. $\mathrm{D}_{4}$-shear zones occur more frequently in the $\mathrm{SE}$ portion of the study area and become regional structures of $\approx 1$ 1,5 kilometers wide and tens of kilometers long. The WNW-set predominates over the ENE-set southward, and occur as a series of regional parallel WNW-NW-trending traces in map view. Radaelli (1992), considers these features as originated in the Archean and reactivated in the Brasiliano orogeny.

GOLD OCCURRENCES Gold occurrences in the study area occur in hydrothermally altered rocks within or associated with

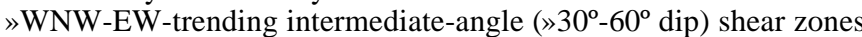
(associated with the $\mathrm{D}_{2}$-episode of deformation in the PSX) or in WNW- to ENE-trending high-angle $\left(>60^{\circ}\right.$ dip) late Brasiliano shear zones (associated with the $\mathrm{D}_{4}$-phase in the PSX). These high-angle shear zones also occur in the southeastern portion of the SBB (Fig. 1).

Specifically in the Pirineus Syntaxis region, the main gold occurrences (Cachoeira do Abade, Fazenda da Viúva, Fazenda Santa Maria and Serra de Santo Antônio) are hosted by silica enrichment structures (quartz lens and silica segregations), preferentially located in the hinge zones of S-SE-verging tight to isoclinal folds and locally in boudinaged veinlets in the limbs of mesoscopic $\mathrm{D}_{2}$-folds. These $\mathrm{D}_{2}$ folds have largely $\approx \mathrm{EW}$-trending traces in map view and are associated with EW-trending intermediate to high-angle shear zones that occur as frontal ramps. These frontal ramps are important loci for gold mineralization and part of imbricated thrusts that stack and repeat a sequence of mylonitic muscovite quartzite and garnet muscovite schis (Araújo Filho 1999). Gold also occurs in thrust-related shear zones of the volcanic-sedimentary sequence of Rio do Peixe. Gold mineralizations concentrated in NNW-SSE-trending strike-slip shear zones and thrusts were reported by DNPM/CPRM (1994).

The mesoscopic lenses and segregations are the loci of countless centimetric to metric-wide hydrothermal alteration zones. Chloritization, sericitization, tourmalinization and sulphidization (pyrite and arsenopyrite) frequently occur in these alteration zones. High modal proportions of epidote and carbonate occur, when amphibolite is affected by hydrothermal alteration. However, quartz veins and silica segregation are absent. Gold is very fine-grained and is only evidenced by chemical analysis, which indicate values of 0,21 ppm for carbonate-rich amphibolite, 0,28 to $0,60 \mathrm{ppm}$ for quartz-mica schists, and 0,70 to 20,00 ppm for quartz lens.

In SE-Goiás, the XVIII-century gold excavations in the town of Silvânia are distributed in a dextral, N40W-trending vertical strike-slip shear zone that affects mafic and ultramafic metavolcanics and carbonaceous schist. These rocks are part of the Silvânia volcanicsedimentary sequence. In the central part of the shear zone those lithologies display mylonitic foliation, bordered by products of hydrothermal alteration such as chloritization, carbonatization, albitization, silicification, sericitization and sulphidization. Finegrained gold, carbonate and pyrite, occur in quartz veins within the shear zone. Chemical analysis of some quartz veins samples indicate 4 g/ton gold (Oliveira et al. 1992).

Also in the SE-portion of the SBB, the gold occurrences at $\approx 7$ and $10 \mathrm{~km}$ to the southwest of the town of Pires do Rio (Strieder 1994), occur close to a N10W-trending thrust-sense shear zone (Fig. 1). The Santa Cruz occurrence is hosted by hydrothermally altered and deformed garnet-biotite granite, intrusive in granulite of the AnápolisItauçú Complex. Gold is identified as native, very finely-grained $(<1$ $\mathrm{mm}$ ) in a 2-4-meter wide and $50 \mathrm{~m}$-long quartz vein, located at the internal rim of the granite body (endocontact). This contact displays a mylonitic foliation. Large crystals of calcite (up to $10 \mathrm{~cm} \mathrm{long}$ ), are very abundant in this vein. When close to the vein, garnet in the mylonitic granite is totally altered to chlorite. Several auriferous quartz veins have been also identified at the external rim of a biotite granite pluton (exocontact), approximately $2 \mathrm{~km}$ to the north of the town of Santo Antônio da Esperança. Veins are generally $20 \mathrm{~cm}$ wide, striking EW, inside a N60W-trending shear zone. Hydrothermal alteration occurs as tourmalinization, chloritization, sericitization, carbonatization and kaolinization. Boxworks of carbonate and pyrite are frequent in the veins. Gold occurs associated with malachite, the main concentrations being found in boudinaged veins.

Apart from important industrial materials deposits (quartzite and limestone), many gold, tin, emerald, kyanite and barite mineralizations have been reported in the study region (e.g. Araújo Filho and Leonardos 1986 a, b, DNPM/CPRM 1994, Giuliani and Araújo Filho 1990, Hoerlle and Wolff-Klein 1977, Ferreira Filho and Brito de Souza 1981).

\section{STRUCTURAL CONTROLS OF GOLD OCCURRENCES}

Gold deposits in the study area are both primary and secondary placer deposits. Primary deposits are predominantly hosted by quartz veins, that are frequent in intermediate- to high-angle shear zones, characterizing a strong structural control for the gold mineralization. However, hydrothermal alterations do occur and are often associated to veining.

We propose that two basic controls exist for the gold mineralization in the study area: i) a magmatic control, e.g. action of fluids from the S- and A-types early-Brasiliano plutonic bodies in the area. To A-type granitoids (e.g. Fazenda Raizama and Arturlândia granitoids in the PSX region), associated greisenization, pegmatitization and locally, metasomatic processes that play an important role in primary veining formation; ii) a structural control, due to the Brasiliano deformation that formed the orogenic province where the Brasília belts are located. The deformation overprinted early structures and was so striking and pervasive that obliterated primary controls in many localities. The deformation also triggered a strong remobilization process of fluids that transported and locally generated gold mineralization (e.g. Serra do Santo Antônio, Serra do Jaraguá, Cachoeira do Abade and Fazenda Santa Maria). Only close to granitoid bodies we observe strong hydrothermalism and pegmatite formation, generally overprinted by the Brasiliano deformation. Away from these bodies (maximum distance of $\approx 12 \mathrm{~km}$ ), few deformed pegmatite veins occur. The known gold mineralization occurrences in the study area (Fig. 1) strongly suggest that structural controls prevail over primary controls. The structural controls are mainly due to ductile-brittle deformation regimes in high-angle EW-trending lateral ramps of E-verging thrusts, intermediate-angle frontal ramps of S-SE-verging thrusts, and highangle WNW-NW-shear zones related to late Brasiliano strike-slip faults.

FINAL REMARKS So far, gold mineralizations do not occur as large economic deposits in the study area (the closest largest economic deposit is mined in regional Riedel fractures near the town of Aurilândia, $\approx 180 \mathrm{~km} \mathrm{~W}$ of the town of Silvânia).

Known geologic data do not define geologic processes related to the formation of gold mineralizations. However, magmatic hydrothermal fluids played an important role in gold transport and deposition. The evidences are: i) gold mineralizations in the proximity of pegmatite veins in granitoid bodies in the Pirineus Syntaxis region. These pegmatite bodies contain tourmalines, tin and quartz veins containing gold; ii) pyrrhotite-bearing granitoids intrusive in the Silvânia volcanic-sedimentary sequence (Vianópolis region) that contain gold up to $0.73 \mathrm{ppm}$ in pyrrhotite. These granitoids produced intense peraluminous hydrothermal alteration in the Silvânia sequence (Freitas and Kuyumjian 1995); iii) exo- and endocontacts of plutonic bodies intrusive in the Anápolis-Itauçú Complex that host gold mineralizations in the Pires do Rio region.

We propose that structural control has dispersed and relocated the primary gold concentrations, which might have been strongly localized in the rims of or within granitoid bodies prior to the deformation. Later metamorphic fluids due to shearing formed gold segregations from both primary sources and disseminated occurrences in metasedimentary rocks (e.g. quartzite and carbonaceous schist from Silvânia). These metasedimentary rocks have background values of $4.40 \mathrm{ppm}$ and $0.28 \mathrm{ppm} \mathrm{Au}$, respectively (Freitas 1994). One of the important sources for the occurrence of tourmaline in the study area is boron, originally deposited in the sediments of the Araxá Group. Another possible source might have been the plutonic bodies in the area.

Therefore, as an exploration strategy, we suggest that more detailed studies should preferentially be carried out on brittle-ductile Brasiliano shear zones veining targets. Late reactivated post-Brasiliano fracture systems should also be considered as targets, since these fractures might constitute loci of reworked gold concentrations from remobilized material of shear zones. 


\section{References}

Araújo Filho J.O. de. 1980. The geology of the Pirineus Megainflection, Goiás, Central Brail 7.Geowibenschaftliches Lateinamerika Kolloquium, Heidelberg,

Araújo Filho, J.O. de. 1981. Contribuição à estratigrafia e tectônica da Megainflexão do Pirineus. In: SBG, Simp. de Geologia do Centro Oeste, 1, Goiânia, Resumos Expandidos, $24-26$

Araújo Filho J.O de. 1992 a. A estrutura do granitóide de Fazenda Raizama: um exemplo de uma mega dobra-em bainha na Mega-Inflexão dos Pirineus. In: Instituto de Geociências-UnB, I Simp. de Geociências, Resumos, 1:17.

Araújo Filho J.O de. 1992 b. The Pirineus Megainflection in central Brazil: an example of a poly-deformed Brasiliano fold-thrust belt. In: Geowibenshaftliches Lateinamerika Kolloquium, 13, Münster, Kurzfassungen, 18-19.

Araújo Filho J.O. de. 1999 a. Structural characteristics and tectonic evolution of the Pirineus Syntaxis, Central Brazil. University of Illinois at Urbana-Champaign, USA Pirineus Syntaxis, Centr.
Ph.D. Thesis, 433 p.

Araújo Filho J.O. de. 1999 b. A Sintaxe dos Pirineus: um exemplo de dois cinturões Brasilianos no centro oeste do Brasil. In:SBG, Simpósio de Geologia do Centrooeste 7 e Simpósio de Geologia de Minas Gerais 10, Brasília, Resumos, 79

Araújo Filho J.O. de and Kuyumjian R. M. 1996. Regional distribution and structural contro of gold occurrences/deposits in the Goiás Massif and Brasília. Rev. Bras. de Geociências, 26(2):109-112.

Araújo Filho J.O.de \& Leonardos, O.H. 1986a. A esmeralda do município de Pirenópolis um exemplo de greisenização de talco-xistos. In: SBG, Congr. Bras. Geol. 34, Anais, 4:1835-1845

Araújo Filho J.O. de \& Leonardos O.H. 1986b. A gênese da esmeralda de Pirenópolis, Goiás. Anais Acad. Bras. de Ciências, 58: 503-504.

Araújo Filho J.O. de \& Roscoe J.S.. 1994. A redefinição tectono-estratigráfica e cinemática do cavalgamento Araxá/Paranoá na porção oriental da Megainflexãp dos Pirineus In: SBG, Congr. Bras. Geol., 38, Camboriú, Anais, 290-292.

Araújo Filho J.O. de \& Marshak S. 1997. Formation of the Pirineus Syntaxis: evidence for two episodes of Brasiliano (Pan African) deformation in the Brasília Orogenic Belt, Central Brazil. GSA Abstract with Programs A-228, BTH 44, Salt Lake City.

DNPM/CPRM. 1994. Pirenópolis, Folha SD-22-Z-D-V, Estado de Goiás, Texto Explicativo: Programa de Levantamentos Geológicos Básicos do Brasil, 108p.
Ferreira Filho C.F. \& Brito de Souza P.C. 1981. Geologia da região norte da Megainflexão dos Pirineus, Goiás - Área 14: Departamento Geociências, Universidade de Brasília, Relatório final de gradução. Inédito.

Fischel D.P., Pimentel M.M., Fuck, R.A. 1998. Idade do metamorpfismo de alto grau no com-plexo Anápolis-Itauçú, Goiás, determinado pelo método Sm-Nd. Rev. Bras. Geociências., 28(4):543-544.

Freitas M.E. de. 1994. Hidrotermalismo na região de Vianópolis, Goiás. Inst. Geociências, Universidade de Brasília, Brasília, Dissertação de Mestrado, 46 p.

Freitas M.E. de. \& Kuyumjian R.M. 1995. Variação química das micas durante o hidrotermalismo peraluminoso de Vianópolis, GO. Boletim de Geociências do Centro-Oeste, 18(1-2):44-56.

Giuliani G. \& Araújo Filho J.O. de. 1990. Padrão de terras-raras nos granitóides de Arturlândia e Quebra-Rabicho (Região de Pirenópolis-Goianésia). Relação com a 34.

Hoerlle M. \& Wolff-Klein, P.B. 1977. Geologia da região de Pirenópolis-Corumbá de Goiás - Área 5 - Serra do Quebra Rabicho:, Departamento de Geociências- Universidade de Brasília, Relatório final de graduação, Inédito.

Oliveira W.R.de, Leonardos, O.H., Kuyumjian, R.M., Martins, E.S. 1992. Ocorrências de ouro de Silvânia, Goiás. In: SBG, Congr. Bras. Geol., 37, São Paulo, Resumos Expandidos $1,227-228$

Radaelli V.A. 1992. Archean basement structural features overprinted by Araxá Proterozoic Orogeny and related gold, tin and emerald deposits in Goiás In: SBG, Congr. Bras. Geol., 37, São Paulo, Resumos Expandidos, 223-224.

Strieder A.J. 1994. Controle estrutural dos veios auríferos de quartzo na região de Santa Cruz de Goiás. In: Congr. Bras. Geol., 38, Camboriú, Resumos Expandidos, 143145.

Contribution IGC-169
Received March 8, 2000 Accepted for publication May 15, 2000 